\title{
Practices of Primary Schools Cluster Supervision: The Case of Jimma Town Primary Schools in Ethiopia
}

\author{
Kasahun Tadele, MA \\ Mitiku Bekele, PhD \\ Jimma University, College of Education \& Behavioral Science \\ Department of Educational Planning and Management
}

doi: 10.19044/esj.2017.v13n17p124 URL:http://dx.doi.org/10.19044/esj.2017.v13n17p124

\begin{abstract}
The purpose of the study was to investigate the Practices of Cluster Supervision in Jimma town primary schools. To achieve this purpose, descriptive survey research design was employed as it helps to describe the status of the cluster supervision. Accordingly, 11 primary schools were selected by using stratified sampling technique from five Cluster Resource Centers (CRCs). From the 11 primary schools 126 teachers were selected using simple random sampling technique to represent the population. Moreover, 26 school principals, 5 CRC supervisors, and 1 Education Office Supervision Coordinator were included by purposefully. Data were collected using questionnaires, interview, observation and document analysis. Frequency, percentages, Mann Whitney U Independent Sample Test and Chi-square were used to analyze the quantitative data. The qualitative data was analyzed thematically. Consequently, the obtained results revealed that the CRC supervisors were not effective in promoting teachers professional development and instructional skills. They were not also able to frequently visit schools and classroom for closer support. Even though cluster supervisors support the schools' management in ensuring good governance and providing timely information, they were not able to adequately enhance the school principals’ planning, decision making and internal management capacity. Moreover, the supervision practice was not successful in creating strong collaboration between all stakeholders. In conclusion, cluster school supervision is highly challenged due to lack of practical competence and adequate preparation of supervisors on one hand and the poor working conditions of supervisors on the other hand. Therefore, it is recommended that Regional Education Bureau and Jimma Town Education Officers work in collaboration with Jimma College of Teacher Education and Jimma University to provide adequate training for cluster supervisors in the town.
\end{abstract}


Jimma town supervision coordinator should also work very closely with the cluster supervisors in identifying the important training needs and providing accordingly to improve the quality of supervision that impact positively the quality teaching and learning. Finally, the Jimma Twon Education Office should allocate adequate budget and create conductive working conditions to achieve the objectives of teaching and learning.

Keywords: Cluster Resource Center, Cluster supervisor, supervisory practice, primary schools

\section{Introduction}

Supervision has been a crucial tool to improve the quality of education of any educational programs of nations including Ethiopia. The goal of supervision is mainly ensuring quality of teaching and enhancing student learning. It fosters improvement in instruction, enhances learning outcomes, and promotes professional development of teachers (Bays, 2001). Moreover, Educational supervision is underscored by many researchers such as Hoy \& Forsyth, (1986); Sullivan \& Glanz, (1999) that it has a great contribution to the improvement of classroom practices, teachers' professional growth and instructional improvement. Govinda and Tapan (1999) taking the case of primary schools in to account also pointed out that supervision is a key factor for ensuring the proper functioning teaching and learning. Therefore, to respond to the great need for a change in the quality of education and meet standards, it becomes necessary to strengthen the school supervision.

De Grauwe (2001) in his study of trends of school supervision service in four African countries pointed out that supervisors provide in service training for the teachers; support curriculum development; hold conferences, and meetings with school staff and monitor teachers' resource centers. This shows that supervision is a quality monitoring tool in schools.

Many countries including Ethiopia, nowadays, have a serious concern of improving the quality of education because sustainable growth and development of nations depends on the quality of the education they provide to citizens. In this regard, Barro (2006) cited in Baffour-Awuah (2011) and De Grauwe (2001) confirmed that the priority of all countries, particularly the developing ones, is to improve the quality of schools and students' learning outcomes. Quality education partly depends on how well teachers are trained and supervised since teachers are one of the key inputs to quality education delivery (Lockheed \& Verspoor, 1991). Many national authorities, therefore, rely on the school supervision system to monitor both the quality of schools and student achievement (De Grauwe, 2001). 
In Ethiopia, the supervisory service has been practiced since 1941 with constant shift of its names between "Inspection" and "Supervision". In the very beginning, supervision was used to focus on controlling teachers than providing support as a result its main purpose was inspection. The tasks of the then inspectors mainly focus on inspecting financial matters than educational programs (Getachew, 2001). Presently, supervision in Ethiopia is development oriented, and educational supervisors are expected to undertake three sets of tasks: controlling, providing support and evaluating results to achieve the unified and standardized school system The role of supervision is ensuring curriculum implementation, providing direct technical support and on the job to teachers, conducting program evaluation, monitoring and coordination in the way that contributes for the improvement of education quality (MoE, 2012).

Ministry of Education strongly believes that proper school supervision is vital to improve the quality of learning. As a result, in the national initiative to improve General Education Quality Improvement Package (GEQIP) which was launched in 2008 and become an integral part of ESDP IV considered school/cluster supervisors as one of the major components to improve the quality of education in Ethiopia (MoE 2010). Ethiopia established school cluster centers to provide supervision and support to the cluster schools. The purpose of school clustering was to bring supervision closer to school level by creating additional layer between the district and the school level (IIEP-UNESCO, 2007). School clustering is established to provide an administrative and pedagogic support to teachers and considered as an effective decentralized means of developing primary education with full school community participation (Giordano, 2008). For Giordano (2008) school clusters are grouping of schools for educational and administrative purposes. De Grauwe (2001a:17) also conceptualizes the purpose of school clustering as provision of a closer and more regular supervision for schools.

In Ethiopia school cluster is an important way to improve the quality of teaching and learning through the provision of closer support to the schools and teachers (MoE, 2006). Supervisory functions in Ethiopia has two fields of application such as pedagogic and administrative (MoE, 2012). In the context of this study, educational supervision conducted by CRC supervisors is conceptualized as aspects of supervision such as staff development, instructional improvement and the management schemes. Thus, it is necessary to see supervision as provision of adequate and appropriate professional support to teachers and schools in the area of pedagogy and administration.

School cluster supervisors are supposed to be professionally competent and able to provide technical support required in their CRCs on 
the aforementioned aspects. In this regards, studies conducted on the issue indicated that the inappropriate selection and appointment of supervisors results in ineffectiveness in discharging responsibilities (De Grauwe, 2001). With this regard, Giordano (2008) states that school clusters have shown disappointing results in terms of improving teaching and, at worst, in achieving the intended goals.

Moreover, school supervisors are found to focus more on administrative issues than pedagogical aspects and lack of necessary skills and training to provide support for teachers and head teachers (MoE, 2001). In connection with this, MoE (2006) also indicated that the school clusters have not been able to fulfill the original intension of improving the capacity of teaching and learning in the schools. Despite the fact that the government of Ethiopia has been providing various trainings to strengthen the supervisors' capacity in order to augment their supervisory skills and improve their practices, their contribution to the improvement of the quality of education is has found to be low (MoE, 2001).

To effectively and efficiently achieve the quality education, therefore, school supervision (external) and the school based (in schools) supervision was introduced in to the education system of our country (Million, 2010; Tesfaw \& Hofman, 2012). The former is carried out by external supervisors at federal, regional, Woreda and/or CRC level while the latter is conducted at the school level by principals, department heads, unit leaders and senior teachers. Though the internal supervisors were supposed to play the main role of supervision for instructional improvement; they were found hardly successful. As a result greater responsibility of school supervision in Ethiopian context is left to the cluster school (CRC) supervisors.

To this end, attempt was made to assess the practice of primary school cluster supervision in Jimma Town. Practices of Jimma town primary school supervision has been continuously reported to fail to provide adequate support for the teachers and school principals in providing professional development trainings, pedagogical skill improvement trainings as well as administrative capacity building to improve the quality of teaching. The schools lack confidence to share instructional resources; supervisors fail collaborate with teachers, schools and other stakeholders to share good practices and experiences. Moreover, the researchers' observation of Jimma town primary schools while participating in various education meetings with public and education professionals at district and regional levels triggered them to conduct a study in the area of the roles and practices of cluster supervision. Therefore, this study mainly focuses on the external supervision by CRC supervisors since it is assumed to provide closer and stronger assistance to schools to bring about the expected level of school improvement. 


\section{Statement of the Problem}

Educational supervision is a continuous process that aims at improving teaching and learning as well as the school management practices. It also encompasses responsibilities of schooling including administration, curriculum, professional development and instruction to improve the quality of education (Glickman, Gordon \& Ross-Gordon, 2005; Oliva \& Pawlas, 1997, and Wiles \& Bondi, 1996). This shows that supervision refers to educational activities that focuses not only on the provision of support to teachers to improve students' performance but also to support management of the curriculum, professional development schemes and instruction to improve quality of educational service in school.

De Grauwe (2001) pointed out that school supervisors give high priority to administrative tasks than pedagogical support. Al-Hammad (2000) and Blumberg (1980) revealed that supervision experiences lack of trust, weak relationship and lack of mutual understanding between teachers and supervisors. Chanyalew (2005) and Million (2010) also revealed that secondary school supervisors of Hadya and West Arsi zone are ineffective and inefficient in providing instructional support to improve classroom teaching and learning.

Various studies conducted in Ethiopian context focuses on instructional supervision in different zones and regions however, to the researchers' knowledge no systematic study was conducted on the practices of primary school cluster supervision in Jimma zone, Jimma town. Based on the principals' and teachers' complaints as well as the researchers' observations, the CRC supervisors practices in providing adequate professional support to schools and the teachers is not to the expected level in bringing the required level of understanding among schools, teachers, principals and education officers by sharing good experience, materials and skills to minimize problems they face. Moreover, they were found to bias towards administrative work and evaluation rather than providing support.

The problems aforementioned in Jimma Town were not confirmed with systematic study though they undeniably can affect the quality of education in Jimma primary schools since supervision is a key component for quality enhancement. It is for this reason the researchers initiated to conduct a systematic and scientific study fill the gap observed between the expectations and actual practices of cluster supervisors.

Therefore, this study attempted to assess the supervision practices in light of the extent to which CRC supervisors contribute to enhance professional development of teachers and benefit Primary Schools in Jimma Town in improving students' achievement and school management practices and promote collaboration among stakeholders. Investigation was also made to identify the major challenges that affect the supervisors' role in carrying 
out their main tasks to achieve the educational goals of the country. This study, therefore, aimed to answer the following basic research questions:

1. To what extent do the primary school cluster supervisors provide professional and instructional/ pedagogical support to enhance staff development?

2. In what ways do primary schools cluster supervisors support the school leadership to improve their management practices?

3. To what extent primary school cluster supervisors promote collaboration among member schools, principals, teachers, and education officers?

4. What challenges primary school cluster supervisors face in carrying out supervisory tasks?

\section{Objectives of the Study}

The general objective of this study was to investigate cluster supervision practices of primary schools in Jimma Town, and determine the major challenges the supervisors face in carrying out their supervision tasks. Attempts were made:

1. to identify the extent to which the primary school cluster supervisors provide professional and pedagogical support to enhance staff development;

2. to examine the extent to which primary school cluster supervisors support the school leadership to improve their management practices;

3. to investigate the extent to which the primary school CRC supervisors promote collaboration among member school principals, teachers, and education officers; and

4. to identify the major challenges that primary schools cluster supervisors face in carrying out supervision tasks

\section{Significance of the Study}

The results of this study will help Regional Education Bureau, Jimma Town Education Office and CRC supervisors to understand contributions and challenges of primary school supervision and take necessary actions to improve it. Help cluster supervisors adjust their supervisory practices in line with teachers' and principals' interest to improve students' performance. It will also help those entrusted with policy formulation to gain better insight into the practice and challenges of cluster supervision and work on preparing better cluster supervisors.

\section{The Research Methodology}

\section{Research Design and Methods}

The study employed explanatory mixed research design for the purpose of the study was to describe and explain the practices of cluster 
supervisors of primary schools in Jimma Town. It mainly used quantitative research method. However, understanding the limitations of using only one type of research method qualitative quantitative data were also collected to triangulate the results of the study. The population of the study comprised 536 primary school teachers, 39 principals and vice principals, five CRC supervisors and one supervisors' coordinator who work in Jimma town, Oromia regional State, Ethiopia.

\section{Sources of Data}

The primary sources of data for this study were the school teachers, principals and primary schools CRC supervisors and Jimma town supervision coordinator. As secondary sources different records like feedback given to supervisors and reports related to supervision were used.

\section{Sample and Sampling Techniques}

Five cluster resource centers (CRCs) in Jimma town were included in the study. There are 17 primary schools clustered under the five clusters where $11(65 \%)$ were selected by using stratified random sampling technique. The stratification was made based on the number of schools and their geographical location. Five CRCs' supervisors, 26 school principals (11 principals and 15 vice principals) and 1 Education Office Supervision coordinator were included by using availability sampling. In addition, 126 teachers were selected by using simple random sampling technique. This randomization method gives equal and independent chance to the population to be included in the sample (Singh, 2006).

\section{Instruments for Data Collection}

Questionnaires were the main data collection instrument supported and triangulated by semi-structured interview, observation and document analysis. The questionnaires were employed and considered appropriate because it can cover a large sample of respondents, thereby allowing a reasonable degree to generalize the findings. The questionnaires were prepared based on literature review and commented by experts for content validity, and also checked for reliability. The reliability of the questionnaires was also checked by using Cronbach's alpha to see the internal consistency. Hence, an average reliability coefficient of 0.870 was established for six themes of the questionnaires.

Semi-structured interview guide was prepared to gather data from supervisors and triangulate the information collected through the questionnaires. Observation checklist was prepared and used to gather data on CRC supervisors' working condition (availability, quality and conditions of facilities) for the supervisors' work. Finally, documents related to 
feedbacks by primary schools CRC supervisors were analyzed to see its adequacy and effectiveness.

\section{Procedures of Data Collection}

The investigators followed series of data collection procedures. First, they prepared questionnaires, interview guides and observation checklists to make the process efficient and effective in achieving the intended objectives of the study. The items for each tool were prepared based on literature review, research questions, goal or objectives of the study as suggested by (Burton, Brundrett \& Jones, 2008). Then, validity and reliability test were made to make improvements on each instrument. To check the reliability of questionnaires Cronbach's alpha was used. In doing this, every ethical issue was taken care of in the study.

\section{Methods of Data Analysis}

Quantitative data were analyzed by using frequency and percentage while the Mann Whitney U Test for independent sample and Chi-square test were utilized to see if differences were observed between teachers' and principals' responses. 'The Mann Whitney U Test was used because it is the most powerful non-parametric test and a distribution free test' (Bethlehem, 2009:198). The qualitative data were thematically analyzed in an integrated way to supplement the quantitative.

\section{Results}

Results of the empirical data generated through questionnaire, semistructured interview, observation and document analysis is presented as follows. The results were presented with adequate response rate of $123(97.6 \%)$ for teachers and $26(100 \%)$ for principals.

Table -1 Respondents' Demographic Characteristics

\begin{tabular}{|c|c|c|c|c|c|c|c|}
\hline \multirow{3}{*}{ Item } & & \multicolumn{6}{|c|}{ Current Positions } \\
\hline & & \multicolumn{2}{|c|}{ Teachers } & \multicolumn{2}{|c|}{ Principals } & \multicolumn{2}{|c|}{ Total } \\
\hline & & $f$ & $\%$ & $t$ & $\%$ & $f$ & $\%$ \\
\hline \multirow{3}{*}{ Sex } & Male & 48 & 39 & 17 & 65.4 & 65 & 43.6 \\
\hline & Female & 75 & 61 & 9 & 34.6 & 84 & 56.4 \\
\hline & Total & 123 & 100.0 & 26 & 100.0 & 149 & 100.0 \\
\hline \multirow{7}{*}{ Age (Years) } & $>25$ & 7 & 5.7 & 0 & 0 & 7 & 4.7 \\
\hline & $26-30$ & 9 & 7.3 & 3 & 11.5 & 12 & 8.1 \\
\hline & $31-35$ & 18 & 14.6 & 4 & 15.4 & 22 & 14.8 \\
\hline & $36-40$ & 23 & 18.7 & 6 & 23.1 & 29 & 19.5 \\
\hline & 41-45 & 42 & 34.1 & 7 & 26.9 & 49 & 32.9 \\
\hline & 46 \& above & 24 & 19.5 & 6 & 23.1 & 30 & 20.1 \\
\hline & Total & 123 & 100.0 & 26 & 100.0 & 149 & 100.0 \\
\hline \multirow[b]{3}{*}{ Education } & Below Certif. & 2 & 1.6 & - & - & 2 & 1.3 \\
\hline & Certificate & 11 & 8.9 & - & - & 11 & 7.4 \\
\hline & Diploma & 86 & 69.9 & 16 & 61.5 & 102 & 68.5 \\
\hline
\end{tabular}




\begin{tabular}{cccccccc}
\hline \multirow{2}{*}{ Qualification } & Degree & 24 & 19.5 & 10 & 38.5 & 34 & 22.8 \\
\cline { 2 - 7 } & Total & $\mathbf{1 2 3}$ & $\mathbf{1 0 0 . 0}$ & $\mathbf{2 6}$ & $\mathbf{1 0 0 . 0}$ & $\mathbf{1 4 9}$ & $\mathbf{1 0 0 . 0}$ \\
\hline \multirow{5}{*}{ Field of study } & EdPM & 5 & 4.1 & 4 & 15.4 & 9 & 6.0 \\
& Social science & 41 & 33.3 & 10 & 38.5 & 51 & 34.2 \\
& Natural & 39 & 31.7 & 6 & 23.1 & 45 & 30.2 \\
& science & & & & & & \\
& Others & 38 & 30.9 & 6 & 23.1 & 44 & 29.5 \\
\cline { 2 - 7 } & Total & $\mathbf{1 2 3}$ & $\mathbf{1 0 0 . 0}$ & $\mathbf{2 6}$ & $\mathbf{1 0 0 . 0}$ & $\mathbf{2 6}$ & $\mathbf{1 0 0 . 0}$ \\
\hline \multirow{5}{*}{ Experience } & $1-5$ & 6 & 4.9 & 1 & 3.8 & 7 & 4.7 \\
(Years) & $6-10$ & 5 & 4.1 & 3 & 11.5 & 8 & 5.4 \\
& $11-15$ & 14 & 11.4 & 2 & 7.7 & 16 & 10.7 \\
& $16-20$ & 28 & 22.8 & 7 & 26.9 & 35 & 23.5 \\
& $21-25$ & 26 & 21.1 & 3 & 11.5 & 29 & 19.5 \\
& 26 \& above & 44 & 35.8 & 10 & 38.5 & 54 & 36.2 \\
\hline \hline
\end{tabular}

As shown in table 1 item 1 , the majority of teachers' respondents were females 75(61\%) under teachers category, but under the principals' category the opposite was true since $17(65.4 \%)$ of principals were males. From all the data in the above tableand interview response of supervisors regarding their gender, female teachers were dominating the teaching position while males were dominating the leadership positions.

Concerning respondents' age, the majority of the respondents $42(34.1 \%)$ of teachers and $7(26.3 \%)$ of the principals were found between the age category of $41-45$ years. Similarly, 24(19.5\%) and 6(23.1\%) of the respondents were under the same age category of 46 years and above as shown in each category. Concerning, the age of CRC supervisors, all of them found between 41-45 years of age. This showed that most of the research participants in the study area are matured enough and can respond well on the current practices of CRC supervisors.

The results of table 1 item 3 also showsthat majority of the study participants i.e. 86(69.9\%) and 16(61.5\%) of teachers and principals had diploma respectively. Whereas, 24(19.5\%) of teacher respondents and 10(38.5) principals had first degree. Totally, 102(68.5\%) participants were professionally trained with diploma. Based on the policy of MoE, Ethiopian teachers and principals of primary schools are expected to have diploma to work in primary schools. Concerning the qualification of the CRC supervisors all of them had diploma except the one who had degree. The CRC supervisors also expected to have diploma in education qualification to work as a supervisor OREB (2007). Hence, most of the respondents in this study are professionally qualified and this can have its own influence for effective supervision and quality of education.

As can be seen in the same Table item 4, teacher respondents had relatively close distribution among the three fields of studies (social science, natural science and others like Languages and Mathematics) which were 
represented by 41(33.3\%), 39(31.7\%) and 38(30.9\%) respectively as we see the field of study listed down the column of the table. On the other hand, $10(38.5 \%)$ of the principals were social sciences while each of the natural science and others field of studies represented by 6(23.1\%) of school principals. Only 4(15.4\%) of the principals are professionally qualified with Educational Planning and Management. This implies that teachers have good distribution on the fields of study while the majority of principals lack professional training on educational management. Thus, the participation of teachers and principals from different field of study has a good contribution for this study to get better information from all the samples. Concerning, the CRC supervisors' field of study, only one is trained professionally in Educational Planning and Management while others come from other fields like Mathematics, Geography and Languages. This can be a result of the guideline which allows teachers from different field can work as a supervisor because of their experience. In the OREB Supervision Manual any teachers with five year work experience from any field can be a supervisor.

The result in table 1 item 5 further depicts the participants' work experience. Accordingly, the majority of the respondents 44(35.8\%) of teachers and $10(38.5 \%)$ of the principals were 26 years and above. The response also revealed that $28(22.8 \%)$ of teachers and $7(26.9 \%)$ principals were found to be under the category of 16-20 years of service. All the CRC supervisors also highly experienced in working as teachers and principals except the one who begun last year. The overall category also proves that highly experienced teachers and principals are dominating the primary schools of Jimma town. Basing on the national standard of career structure of Ethiopia, the majority of teachers and principals of Jimma Town government primary schools are very much experienced in teaching, and can be labeled as Associate Head Teachers and Head Teachers.

Table 2: CRC Supervisors' Professional Support to Staff Development

\begin{tabular}{|c|c|c|c|c|c|c|c|c|c|c|c|}
\hline \multirow{4}{*}{ Items } & \multirow{4}{*}{ Respondents } & \multicolumn{10}{|c|}{ Note: $\mathrm{N}=149$ i.e. 123 teachers and 26 principals } \\
\hline & & \multicolumn{8}{|c|}{ Responses } & \multirow{2}{*}{\multicolumn{2}{|c|}{ Total }} \\
\hline & & \multicolumn{2}{|c|}{ Never } & Rarely & \multicolumn{2}{|c|}{ Sometimes } & Often & \multicolumn{2}{|c|}{ Always } & & \\
\hline & & $\boldsymbol{F}$ & $\%$ & $\%$ & $\boldsymbol{F}$ & $\%$ & $\%$ & $f$ & $\%$ & $f$ & $\%$ \\
\hline The CRC supervisors provide & Teacher & 39 & 31.7 & 3528.5 & 33 & 26.8 & 86.5 & 8 & 6.5 & 123 & 100 \\
\hline induction trainings to & Principal & 12 & 46.2 & 311.5 & 5 & 19.2 & 415.4 & 2 & 7.7 & 26 & 100 \\
\hline & Total & 51 & 34.2 & 3825.5 & 38 & 25.5 & 128.1 & 10 & 6.7 & 149 & 100 \\
\hline The CRC supervisors & Teacher & 27 & 22.0 & 3730.1 & 37 & 30.1 & 1713.8 & 5 & 4.1 & 123 & 100 \\
\hline demonstrate suitable teaching & Principal & 7 & 26.9 & 311.5 & 11 & 42.3 & 415.4 & 1 & 3.8 & 26 & 100 \\
\hline & Total & 34 & 22.8 & 4026.8 & 48 & 32.2 & 2114.1 & 6 & 4.0 & 149 & 100 \\
\hline The CRC supervisors promote & Teacher & 48 & 39.0 & 2923.6 & 27 & 22.0 & 1411.4 & 5 & 4.1 & 123 & 100 \\
\hline professional development of & Principal & 5 & 19.2 & 726.9 & 7 & 26.9 & 519.2 & 2 & 7.7 & 26 & 100 \\
\hline
\end{tabular}


teachers in and outside schools through short term training, workshops and seminars.

The CRC supervisors provide objective feedback on classroom observation.

The supervisors encourage teachers to conduct action research to solve problems.
Total

$53 \quad 35.636 \quad 24.2 \quad 34$

$\begin{array}{lll}22.8 & 19 & 12.8\end{array}$

$\begin{array}{llll}7 & 4.7 & 149 & 100\end{array}$

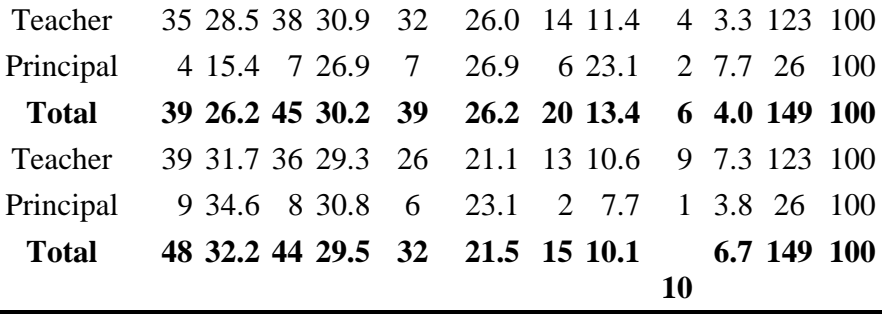

As depicted in table 2, high percentage of the respondents rated that CRC supervisors never (31.7\% of teachers and $46.2 \%$ of principals) provided induction training. When the Mann-Whitney Wallis statistic was calculated to see differences $(\mathrm{U}=1538.0, \mathrm{P}=.751)$, it indicated that there is a statistically no significant difference between the teachers' and principals' responses at significance level of $\alpha=0.05$. This shows that CRC supervisors are not supporting new or beginner teachers to easily socialize and actively involved in the teaching learning and school environment.

The results in table 2 above also showed that the practice of CRC supervisors in demonstrating suitable teaching techniques and methods was rated 'moderate' as confirmed by (30.1\%) of teachers and (42.3\%) of principals' responses. Still (30.1\%) of teachers and (26.9\%) of principals responded that supervisors practice this activity only 'rarely' and 'never' respectively. This implies that CRC supervisors' support to teachers to improve their instructional practices was not sufficient.

Responses for the third item of table 2 revealed that (39\%) teachers and (19.2\%) of principals reported that the practice of cluster supervisors never promote professional development of teachers in and outside schools through short term training, workshops and seminars. However, (26.9\%) of the principals responded as they experienced this practice rarely and sometimes. In addition, (23.6\%) of teachers rarely experienced the practice on this aspect. In the interview, CRC supervisors indicated that they were not conducting such formal training, workshops and seminars. From the obtained data, it is possible to infer that supervisors are not to the expectation in conducting need based short term trainings, seminars and workshops to enhance teachers' capacity.

Concerning, the practice of CRC supervisors in providing objective feedback on classroom observation, 38(30.9\%) teachers and 7(26.9\%) principals responded that the cluster supervisor provide objective feedback rarely. Nearly (26\%) percent of both respondents also indicated that the cluster supervisor only 'sometimes' provide objective feedback. 
The result of the Mann Whitney $U$ Test for item 3 and 4 shows that there is statistically significance difference at significance level of $\alpha=.05$ between the teachers and principals respondents opinions in which (U= 1211.0, $\mathrm{P}=.044)$ for item 3 and $(\mathrm{U}=1213.0, \mathrm{P}=.046)$ for item 4 . This is because principals' mean rank on each item is higher than the teachers. This shows that supervisors' contribution is low in improving teachers' career through trainings and provision of objective feedback to reflect on what actually took place in the teaching-learning process and for future improvement than the support for the school leadershlip.

The last item of table 2 also showed a majority of teacher and principal respondents (31.7\%) and (34\%) respectively reported that the supervisors 'never' encouraged teachers in conducting action research to solve school problems. Totally, 75(61\%) of teacher and 17(65\%) of principal respondents reported that the CRC supervisors 'rarely' and 'never' encourage teachers in conducting action research.

Document analysis also witnessed that conducting action research in most of the schools was non-existence. For instance, feedbacks given to the government schools in this regard showed, there was an effort to conduct action research only in five schools. Others did not make any effort. This posits that CRC supervisors are not adequately supporting teachers in alleviating immediate problems of their school and classrooms by engaging in action research that will improve students' learning. Therefore, it can be concluded that CRC supervision in Jimma Town primary schools is not good at promoting teachers professional development by building their capacity and providing constructive feedback.

Table 3: Professional Development Benefits gained from Supervision

\begin{tabular}{|c|c|c|c|c|c|c|c|c|c|c|c|c|}
\hline \multicolumn{13}{|c|}{$\mathrm{N}=149$ i.e. 123 teachers and 26 principals } \\
\hline \multirow[t]{3}{*}{ Items } & \multirow[t]{3}{*}{ Respondents } & \multicolumn{9}{|c|}{$\begin{array}{r}\text { Responses } \\
\end{array}$} & & \\
\hline & & \multicolumn{2}{|c|}{$\begin{array}{l}\text { Strongly } \\
\text { disagree }\end{array}$} & \multicolumn{2}{|c|}{ Disagree } & \multicolumn{2}{|c|}{ Undecided } & Agree & \multicolumn{2}{|c|}{$\begin{array}{l}\text { Strongly } \\
\text { agree }\end{array}$} & \multicolumn{2}{|c|}{ Total } \\
\hline & & $\boldsymbol{F}$ & $\%$ & $f$ & $\%$ & $f$ & $\%$ & $\%$ & $F$ & $\%$ & $\boldsymbol{F}$ & $\%$ \\
\hline \multirow{3}{*}{$\begin{array}{l}\text { CRC Supervisors' } \\
\text { classroom visit and } \\
\text { comments improved } \\
\text { teachers' lesson } \\
\text { presentation. }\end{array}$} & Teacher & 32 & 26 & 34 & 27.6 & 19 & 15.4 & 2923.6 & 9 & 7.3 & 123 & 100 \\
\hline & Principal & 7 & 26.9 & 10 & 38.5 & 1 & 3.8 & 519.2 & 3 & 11.5 & 26 & 100 \\
\hline & Total & 39 & 26.2 & 44 & 29.5 & 20 & 13.4 & 3422.8 & 12 & 8.1 & 149 & 100 \\
\hline \multirow{3}{*}{$\begin{array}{l}\text { Teachers are able to interact } \\
\text { with other teachers using } \\
\text { the opportunity provided by } \\
\text { supervisor to discuss on } \\
\text { matters related to teaching } \\
\text { learning process. }\end{array}$} & Teacher & 35 & 28.5 & 31 & 25.2 & 22 & 17.9 & $27 \quad 22$ & 8 & 6.5 & 123 & 100 \\
\hline & Principal & 8 & 30.8 & 9 & 34.6 & 2 & 7.7 & $\begin{array}{ll}6 & 23.1\end{array}$ & 1 & 3.8 & 26 & 100 \\
\hline & Total & 43 & 28.9 & 40 & 26.8 & 24 & 16.1 & 3322.1 & 9 & 6 & 149 & 100 \\
\hline \multirow{2}{*}{$\begin{array}{l}\text { Teachers have improved } \\
\text { selection and use of }\end{array}$} & Teacher & 34 & 27.6 & 38 & 30.9 & 21 & 17.1 & 2318.7 & 7 & 5.7 & 123 & 100 \\
\hline & Principal & 9 & 34.6 & 6 & 23.1 & 3 & 11.5 & $\begin{array}{ll}5 & 19.2\end{array}$ & 3 & 11.5 & 26 & 100 \\
\hline
\end{tabular}




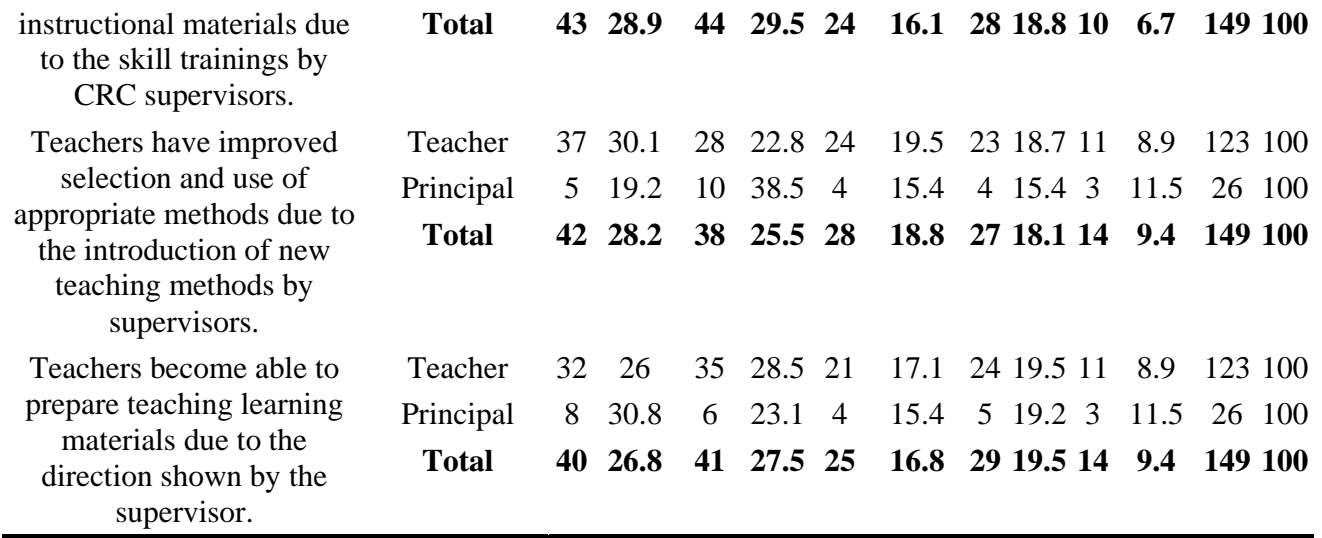

Table 3 above shows 34(27.6\%) teachers and 10(38.5\%) principals disagreed that their CRC supervisors' classroom visit and comments improve teachers' lesson presentation. Still, 32(26\%) of teachers and 7(26.9\%) of principals strongly disagreed with this item. It can be seen that the majority of teachers 66 (53.6\%) and principals17 (64.5\%) do not agree on the contribution of the supervisory service in improving teachers professional competence. Thus, it can be concluded that the practice of the CRC supervisors did not adequately benefit teachers to improve their profession and the classroom practices in lesson presentation.

The same table also shows 35(28.5\%) teachers and 9(34.6\%) principals strongly disagreed on the presence of better teachers' interaction the opportunity provided by supervisor. In sum, majority of teachers (53.6\%) and principals (65.3\%) responded that there no adequate improvement in this regards. Interview conducted with CRC supervisors also confirmed that CRC supervisors are expected to visit many schools with large number of teachers that affected the quality of providing opportunity for effective interaction among teachers.

When respondents were asked whether teachers have improved their selection and use of instructional materials due to the skill trainings by CRC supervisors, as depicted in table 3, 72 (55.5\%) of teachers and 15(57.6\%) of principals disagreed on the benefits teachers get in this regard Which means the supervisory service provided didn't contribute to the expected level.

On the forth item of table $3,37(30.1 \%)$ of teachers were strongly disagreed while $10(38.5 \%)$ of principals disagreed with the item that states teachers have improved selection and use of appropriate methods due to the introduction of new teaching methods by CRC supervisors. Not only this, (22.8\% teachers and $19.2 \%$ principals) disagreed. This revealed that the CRC supervisors are not successful in enhancing teachers' capacity to use the appropriate methods of teaching through adequate professional assistance and technical support. 
With regard to giving direction to teachers to enable them access relevant and appropriate resources, the majority 67(54.5\%) of teachers and 14(53.8\%) of principals responded that the service is inadequate. Therefore, it is possible to say that supervisors are less effective in assisting teachers to access teaching learning resources to better facilitate the classroom practice. Data from document analysis also confirmed that many teachers in Jimma Town mainly use the traditional method of teaching than the active learning methods.

In order to determine if there is any statistically significant differences between responses of the two groups regarding item 1- 5 in Table 3, the Mann-Whitney $U$ test for independent sample was used. As a result, regarding development benefits teachers get from CRC supervisors (See Appendix-6, Table: C). Accordingly, the Mann Whitney U test result for item 1 was $(\mathrm{U}=1530.5, \mathrm{P}=.724)$; for item 2 was $(\mathrm{U}=1476.5, \mathrm{P}=.528)$; for item $3(\mathrm{U}=1598.5, \mathrm{P}=.998)$; for item $4(\mathrm{U}=1533.0, \mathrm{P}=.735)$, and for the last item was ( $\mathrm{U}=1587.5, \mathrm{P}=.953)$. As can be seen from each item's data, there were no statistically significant differences between the responses of teachers and principals since the $\mathrm{p}$ value of each of the item was $>0.05$.

Based on the above data presentation, it is possible to realize that the CRC supervisors' support in improving classroom practices and benefiting teachers by promoting teachers' professional development in general and lesson planning, classroom management, selection and use of instructional materials as well as teaching methods in particular is less successful.

Table 4: Contributions of CRC Supervisors' in Improving Principals' Management Practices

\begin{tabular}{|c|c|c|c|c|c|c|c|c|c|c|c|c|}
\hline \multirow[t]{4}{*}{ Items } & \multicolumn{10}{|c|}{ Note: $\mathrm{N}=26$ principals and vice principals } & \multirow{3}{*}{\multicolumn{2}{|c|}{$\begin{array}{c}\text { Test } \\
\text { Value }=3\end{array}$}} \\
\hline & \multicolumn{10}{|c|}{ Responses } & & \\
\hline & \multicolumn{2}{|c|}{$\begin{array}{l}\text { Strongly } \\
\text { disagree }\end{array}$} & \multicolumn{2}{|c|}{ Disagree } & \multicolumn{2}{|c|}{ Undecided } & \multicolumn{2}{|c|}{ Agree } & \multicolumn{2}{|c|}{$\begin{array}{c}\text { Strongly } \\
\text { agree }\end{array}$} & & \\
\hline & $f$ & & $\% f$ & $\%$ & $f$ & $\%$ & $f$ & $\%$ & $f$ & $\%$ & $M$ & $S D$ \\
\hline $\begin{array}{l}\text { The CRC supervisors provide } \\
\text { training to improve school } \\
\text { management planning skills }\end{array}$ & 8 & 30.8 & 6 & $6 \quad 23.1$ & 3 & 11.5 & 5 & 19.2 & 4 & 15.4 & 2.65 & 1.495 \\
\hline $\begin{array}{l}\text { Supervisors provide evidences to } \\
\text { strengthen school management } \\
\text { decision making skills. }\end{array}$ & 7 & 26.9 & 9 & $\begin{array}{l}9 \\
74.6\end{array}$ & 3 & 11.5 & 5 & 19.2 & 2 & 7.7 & 2.46 & 1.303 \\
\hline $\begin{array}{l}\text { Supervisors consult the school } \\
\text { management on how to ensure } \\
\text { good governance. }\end{array}$ & 4 & 15.4 & 6 & $6 \quad 23.1$ & 5 & 19.2 & 9 & 34.6 & 2 & 7.7 & 3.27 & 1.218 \\
\hline $\begin{array}{l}\text { The CRC supervisors provide } \\
\text { necessary information for school } \\
\text { management timely. }\end{array}$ & 5 & 19.2 & 4 & $4 \quad 15.4$ & 2 & 7.7 & & 46.2 & 3 & 11.5 & 3.15 & 1.377 \\
\hline $\begin{array}{l}\text { Supervisors consult the school } \\
\text { management on how to use } \\
\text { resources efficiently. }\end{array}$ & 8 & 30.8 & 7 & $7 \quad 26.9$ & 3 & 11.5 & 6 & 23.1 & 2 & 7.7 & 2.50 & 1.364 \\
\hline
\end{tabular}


Supervisors help school principals

to participate stakeholders in decision making.

CRC supervisors reinforce the

monitoring and supervision system $4 \quad \begin{array}{lllllllllll}15.4 & 11 & 42.3 & 1 & 3.8 & 10 & 38.5 & 0 & 0 & 2.77 & 1.243\end{array}$ of the school.

The CRC supervisors reward well

performing school principals.

With regard to improvement of school leaders' management practices such as improving principals' planning skills, enhancing decision making skills, ensuring efficient use of resources, participating stakeholders in decision making, enforcing monitoring and supervision and item , and rewarding well performing principals showed that the contribution of CRC supervisors in each factor was low, since the mean test value (3) was higher than that of all the mean values except for item 3 and 4 .

The mean value for helping principals' to ensure good governance $(\mathrm{M}=3.27, \mathrm{SD}=1.218)$ and providing timely information $(\mathrm{M}=3.15, \mathrm{SD}=$ 1.377) revealed that the CRC supervisors' contribution were encouraging in this practice with higher mean than the test value mentioned earlier. This also confirmed in the responses of the majority (34.6\% for the third item and $46.2 \%$ for the forth item). The data clearly showed that cluster supervisors are less successful in contributing to the improvement of school principals' or leaders' management practices except playing a positive role in ensuring good governance and providing necessary information.

Table 5: CRC Supervisors' Practices in Promoting Collaboration

\begin{tabular}{|c|c|c|c|c|c|c|c|c|c|c|c|c|}
\hline \multirow{4}{*}{ Items } & \multicolumn{12}{|c|}{$\mathrm{N}=149$ i.e. 123 teachers and 26 principals } \\
\hline & \multirow[t]{3}{*}{ Respondents } & \multicolumn{9}{|c|}{ Responses } & \multirow{2}{*}{\multicolumn{2}{|c|}{ Total }} \\
\hline & & \multicolumn{2}{|c|}{$\begin{array}{l}\text { Strongly } \\
\text { disagree }\end{array}$} & \multicolumn{2}{|c|}{ Disagree } & \multicolumn{2}{|c|}{ Undecided } & Agree & \multicolumn{2}{|c|}{$\begin{array}{c}\text { Strongly } \\
\text { agree }\end{array}$} & & \\
\hline & & $f$ & $\%$ & $f$ & $\%$ & $f$ & $\%$ & $\%$ & $f$ & $\%$ & $f$ & $\%$ \\
\hline \multirow{3}{*}{$\begin{array}{l}\text { CRC supervisor facilitates } \\
\text { cooperation among member } \\
\text { schools, principals, and } \\
\text { teachers regarding } \\
\text { pedagogical issues. }\end{array}$} & Teacher & 28 & 22.8 & 34 & 27.6 & 19 & 15.4 & 2621.1 & 16 & 13.0 & 123 & 100 \\
\hline & Principal & 5 & 19.2 & 7 & 26.9 & 2 & 7.7 & 1038.5 & 2 & 7.7 & 26 & 100 \\
\hline & Total & 33 & 22.1 & 41 & 27.5 & 21 & 14.1 & 3624.2 & 18 & 12.1 & 149 & 100 \\
\hline \multirow{3}{*}{$\begin{array}{l}\text { CRC supervisor works as a } \\
\text { linking agent vertically to } \\
\text { create strong relationship } \\
\text { between the school and the } \\
\text { district office. }\end{array}$} & Teacher & 25 & 20.3 & 37 & 30.1 & 25 & 20.3 & 2016.3 & 16 & 13.0 & 123 & 100 \\
\hline & Principal & 7 & 26.9 & 5 & 19.2 & 2 & 7.7 & 1038.5 & 2 & 7.7 & 26 & 100 \\
\hline & Total & 32 & 21.5 & 42 & 28.2 & 27 & 18.1 & 3020.1 & 18 & 12.1 & 149 & 100 \\
\hline \multirow{3}{*}{$\begin{array}{l}\text { CRC supervisor brings } \\
\text { principals and teachers } \\
\text { together to work as a team } \\
\text { for the achievement of } \\
\text { objectives. }\end{array}$} & Teacher & 27 & 22.0 & 32 & 26.0 & 18 & 14.6 & 2923.6 & 17 & 13.8 & 123 & 100 \\
\hline & Principal & 4 & 15.4 & 10 & 38.5 & 2 & 7.7 & 623. & 4 & 15.4 & 26 & 100 \\
\hline & Total & 31 & 20.8 & 42 & 28.2 & 20 & 13.4 & 3523.5 & 21 & 14.1 & 149 & 100 \\
\hline CRC supervisor encourage & Teacher & 34 & 27.6 & 33 & 26.8 & 23 & 18.7 & 2318.7 & 10 & 8.1 & 123 & 100 \\
\hline
\end{tabular}




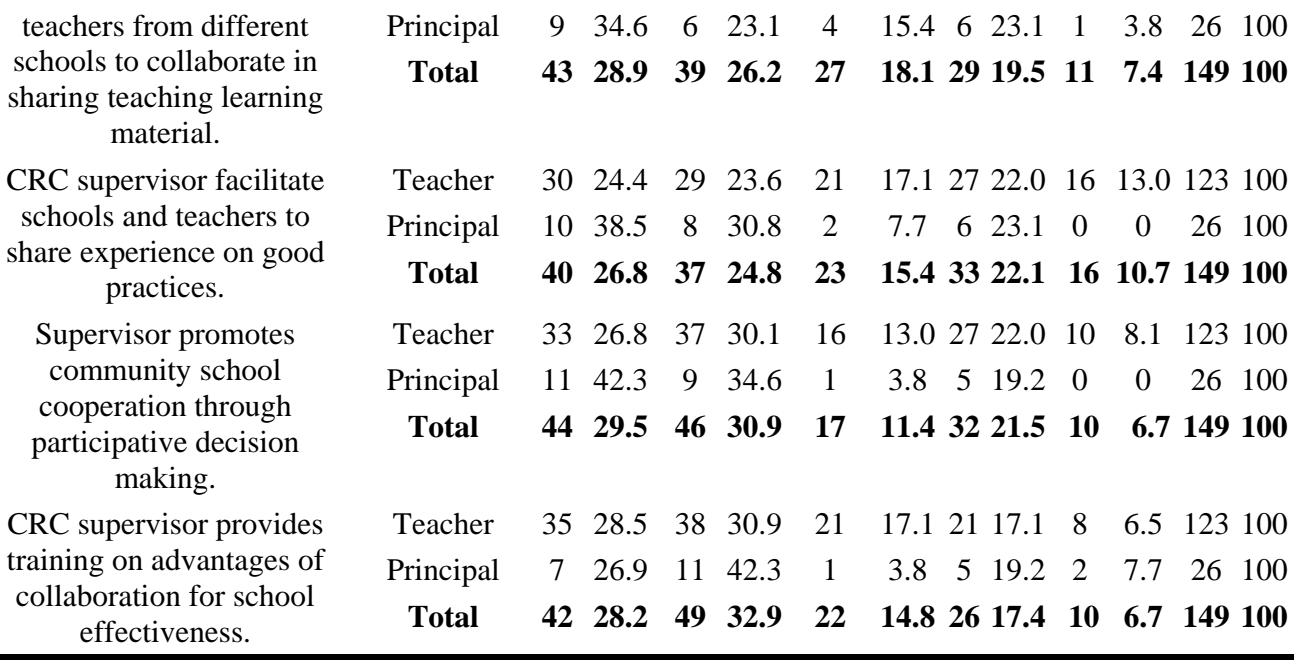

From the respondents' points of view, the data in table 5 disclose that the majority respondents' disagreed in most of the items that were used as indicators of promoting collaboration. Although such negative reflections were observed in most of the items, (46.2\%) principals agreed and strongly agreed (to item 1 and 2) about the existence of collaboration among member schools, principals, and teachers on pedagogic issues as a result supervisors work in playing the role as linking agents between the school and the district office by cluster supervisors. Data from documents analysis also showed that education leaders fail to communicate in the way that help leaders to better discharge their responsibility. This shows that the cluster supervisors failed to promote collaboration.

As to the rest of the constructs of promoting collaboration, the majority of both teachers and principals disagreed with (disagree + strongly disagree) on each item. For instance, as indicated on item (3) bringing principals and teachers together to work as a team to achieving educational objectives were not well practiced as shown by a total of ( $48 \%$ teachers and $53.9 \%$ principals); for item (4) about encouraging teachers to collaborate in sharing teaching learning materials as revealed by the disagreement of (54.4\% teachers and $57.6 \%$ principals); for item (5) about facilitating schools and teachers to share experience on good practices were (48\% teachers and $69.3 \%$ principals) confirmed the limited existence of this practice. Concerning the effort of CRC supervisors on item (6) in promoting community school cooperation through participative decision making, (56.9\% of teacher and $76.9 \%$ of principal) were strongly disagree and disagree on the presence of this practice. On the final item (7) regarding the practice of the CRC supervisors in providing training on advantages of collaboration for school effectiveness, (59\% of teachers and $69 \%$ of 
principals) strongly disagreed and disagreed regarding the existence of training on advantages of collaboration for school effectiveness.

Data from interview and document analysis also confirmed that collaboration was limited. Some schools went to Seto and Dilfre from government schools, Beteseb Academy, and SOS for experience sharing in terms of pedagogic center, how teachers play their roles in the schools and other construction and school improvement program. In the document analysis, it was identified that lack of experience sharing on good practices is the common problems of all the five CRCs. Feedbacks given to the CRC supervisors also confirmed the existence of this problem. Thus, it can be said that supervisors failed to discharge one of their main responsibilities. From this, it is possible to say that CRC supervisors are less successful in enhancing active collaboration between the school and the school community in decision making. In conclusion it is possible to say that CRC supervisors were not promoting strong collaboration between teachers and other stakeholders. They are only creating continuous rapport between school principals and themselves. Therefore, teachers could not engage themselves to share adequate practical experiences, skills and teaching learning materials to achieve educational objectives; still supervisors are not in a position to achieve the fundamental goal of their cluster by improving the quality of teaching and learning at school and classroom levels through providing training to enhance collaboration.

Table 6: CRC Supervisors' Support to Improve Classroom Teaching and Learning

\begin{tabular}{cccccccc}
\hline \multirow{2}{*}{ Item } & \multirow{2}{*}{ Respondents } & \multicolumn{3}{c}{ Responses } \\
\cline { 3 - 7 } & & & \multicolumn{3}{c}{ No } & \multicolumn{2}{c}{ Total } \\
\cline { 3 - 7 } & & $f$ & $\%$ & $f$ & $\%$ & $f$ & $\%$ \\
\hline Do you think the supervisor's over & Teachers & 36 & 29.3 & 87 & 70.7 & 123 & 100 \\
all support improved teaching & Principals & 11 & 42.3 & 15 & 57.7 & 26 & 100 \\
learning in your school? & Total & $\mathbf{4 7}$ & 31.5 & $\mathbf{1 0 2}$ & 68.5 & $\mathbf{1 4 9}$ & $\mathbf{1 0 0}$ \\
\hline
\end{tabular}

As it can be seen in the table 6 above, majority of the teachers (70.7\%) and majority of principals (57.7\%) reported that the overall support of the CRC supervisors did not contribute much in improving the teaching learning practices in the classrooms. A Chi-square test was calculated to check whether opinion differences exist between the two groups or not. Consequently, a Chi-square test result showed that there was no statistically significant differences between teachers' and principals' opinions on this item $\left(\chi^{2}=1.690\right.$, df $\left.=1, \mathrm{p}=.194\right)$. Therefore, it is possible to say that the support of CRC supervisors is not to the expect level in improving the classroom practices

\section{Major Challenges of Supervisory Practices}

In this sub section various challenges were discussed based on 
teachers, principals, supervisors and Jimma town supervision coordinators’ responses.

Table 7: Professional Competence and Preparation Related Challenges of Supervisors

\begin{tabular}{|c|c|c|c|c|c|c|c|c|c|c|c|c|c|}
\hline \multirow{4}{*}{ Items } & \multicolumn{13}{|c|}{$\mathrm{N}=149$ i.e. 123 teachers and 26 principals } \\
\hline & \multirow[t]{3}{*}{ Respondents } & \multicolumn{10}{|c|}{ Responses } & & \\
\hline & & \multicolumn{2}{|c|}{$\begin{array}{l}\text { Strongly } \\
\text { disagree }\end{array}$} & \multicolumn{2}{|c|}{ Disagree } & \multicolumn{2}{|c|}{ Undecided } & \multicolumn{2}{|c|}{ Agree } & \multicolumn{2}{|c|}{$\begin{array}{c}\text { Strongly } \\
\text { agree }\end{array}$} & \multicolumn{2}{|c|}{ Total } \\
\hline & & $F$ & $\%$ & $f$ & $\%$ & $f$ & $\%$ & $f$ & $\%$ & $F$ & $\%$ & $f$ & $\%$ \\
\hline \multirow{3}{*}{$\begin{array}{l}\text { The CRC supervisor properly } \\
\text { qualified to provide the } \\
\text { supervisory service. }\end{array}$} & Teacher & 31 & 25.2 & 30 & 24.3 & 22 & 17.9 & 22 & 17.9 & 18 & 14.6 & 123 & 100 \\
\hline & Principal & 7 & 26.9 & 6 & 23.1 & 2 & 7.7 & 10 & 38.5 & 1 & 3.8 & 26 & 100 \\
\hline & Total & 38 & 25.5 & 36 & 24.2 & 24 & 16.1 & 32 & 21.5 & 12 & 12.8 & 149 & 100 \\
\hline \multirow{3}{*}{$\begin{array}{l}\text { The CRC supervisor is well } \\
\text { experienced in giving proper } \\
\text { professional support. }\end{array}$} & Teacher & 31 & 25.2 & 33 & 26.8 & 23 & 18.7 & 23 & 18.7 & 13 & 10.6 & 123 & 100 \\
\hline & Principal & 5 & 19.2 & 3 & 11.5 & 2 & 7.7 & 12 & 46.2 & 4 & 15.4 & 26 & 100 \\
\hline & Total & 37 & 24.8 & 36 & 24.2 & 25 & 16.8 & 34 & 22.8 & 17 & 11.4 & 149 & 100 \\
\hline \multirow{3}{*}{$\begin{array}{l}\text { The supervisor accepts } \\
\text { responsibility for his/her } \\
\text { decisions as a professional. }\end{array}$} & Teacher & 18 & 14.6 & 26 & 21. & 25 & 20.3 & 38 & 30.9 & 16 & 13 & 123 & 100 \\
\hline & Principal & 2 & 7.7 & 7 & 26.9 & 3 & 11.5 & 11 & 42.3 & 3 & 11.5 & 26 & 100 \\
\hline & Total & 20 & 13.4 & 33 & 22.1 & 28 & 18.8 & 49 & 32.9 & 19 & 12.8 & 149 & 100 \\
\hline \multirow{3}{*}{$\begin{array}{l}\text { The CRC supervisor } \\
\text { efficiently applies the } \\
\text { knowledge he/she gets from } \\
\text { workshops and seminars in } \\
\text { providing support }\end{array}$} & Teacher & 29 & 23.6 & 42 & 34.1 & 22 & 17.9 & 21 & 17.1 & 9 & 7.3 & 123 & 100 \\
\hline & Principal & 5 & 19.2 & 12 & 46.2 & 3 & 11.5 & 4 & 15.4 & 2 & 7.7 & 26 & 100 \\
\hline & Total & 34 & 22.8 & 54 & 36.2 & 25 & 16.8 & 25 & 16.8 & 11 & 7.4 & 149 & 100 \\
\hline \multirow{3}{*}{$\begin{array}{c}\text { The supervisor lacks support } \\
\text { instruments: manuals/guides } \\
\text { and database. }\end{array}$} & Teacher & 32 & 26 & 33 & 26.8 & 29 & 23.6 & 22 & 17.9 & 7 & 5.7 & 123 & 100 \\
\hline & Principal & 6 & 23.1 & 9 & 34.6 & 5 & 19.2 & 5 & 19.2 & 1 & 3.8 & 26 & 100 \\
\hline & Total & 38 & 25.5 & 42 & 28.2 & 34 & 22.8 & 27 & 18.1 & 8 & 5.4 & 149 & 100 \\
\hline
\end{tabular}

As shown in table 7, CRC supervisors are viewed as not properly qualified to provide the supervisory service by 61(50\%) and principals $13(50 \%)$ out of the total respondents. The teachers and principals showed their strong disagreement and disagreement on this issue. However, in the open ended items, one teacher said, "CRC supervisors have degree or diploma as per the criteria, however they doubt that the selection and placement of the supervisors is competitive and merit based. Other mentioned that though the supervisors are qualified they lack the competence to effectively play the supervisory roles.

School principals also described that the supervisors lack professional skills, competence and appropriate training. Moreover, they are not properly selected and lack commitment. Thus it can be fairly concluded that the supervisors lack competence and perform far less than the expectations.

With regard to the experience of the supervisors, 33(26.8\%) of teachers perceive as inadequate, whereas, $12(46.2 \%)$ of principals believe 
that they have adequate experience. When the Mann-Whitney U test statistic was calculated to determine whether there was any statistically significant difference in the responses of the two groups $(\mathrm{U}=1179.0, \mathrm{P}=.031)$, a statistically significant difference was found at $\alpha=.05$ between the teachers and principals responses because $\mathrm{p}<0.05$.

Concerning the extent to which the supervisor accepts responsibility for his/her decisions as a professional, 38(30.9\%) of teachers and 11(42.3\%) of principals agreed that the CRC supervisors accepts responsibility for their decisions as a professional. Evidences from the interview result also revealed similar idea. This shows that supervisors take professional responsibilities for their decision less likely.

Regarding supervisors effectiveness in using effectively the knowledge they get from workshops and seminars to provide quality support, the result showed that $42(34.1 \%)$ of teachers and $12(46.2 \%)$ of principals indicated that they do not effectively utilize. Totally, the majority $71(57 \%)$ of teachers and 17(65\%) of principals disagreed that they apply knowledge gained from such workshops and seminars effectively.

Regarding the last item, a total of (53\% of teachers and 58\% of principals) reported that supervisors are challenged by lack enough support, instruments like manuals, guides and database. However, in the interview with coordinators and CRC supervisors it is revealed that they have the mentioned support. Though the results from interview and questionnaires seem to contradict apparently, it shows that the supervisors were not effectively utilizing resources at hand.

When the Mann-Whitney $U$ test for independent sample has been utilized on each item 1-5 (See Appendix 6, Table: E) no statistically significant differences were found between teachers and principals responses except the second item "the CRC supervisor is well experienced in giving supervisory support" in which $(\mathrm{U}=1179.0, \mathrm{P}=.031)$ since principals mean rank is higher than teachers. The Mann Whitney $\mathrm{U}$ test for item 1 was ( $\mathrm{U}=$ 1582.5, $\mathrm{P}=.933)$; for item $3(\mathrm{U}=1480.5, \mathrm{P}=.542)$; for item $4(\mathrm{U}=1569.5$, $\mathrm{P}=.878)$, and for item $5(\mathrm{U}=1574.5, \mathrm{P}=.900)$ at $\mathrm{p}>0.05$. 
Table 8: Work Conditions Related Challenges of Supervisors

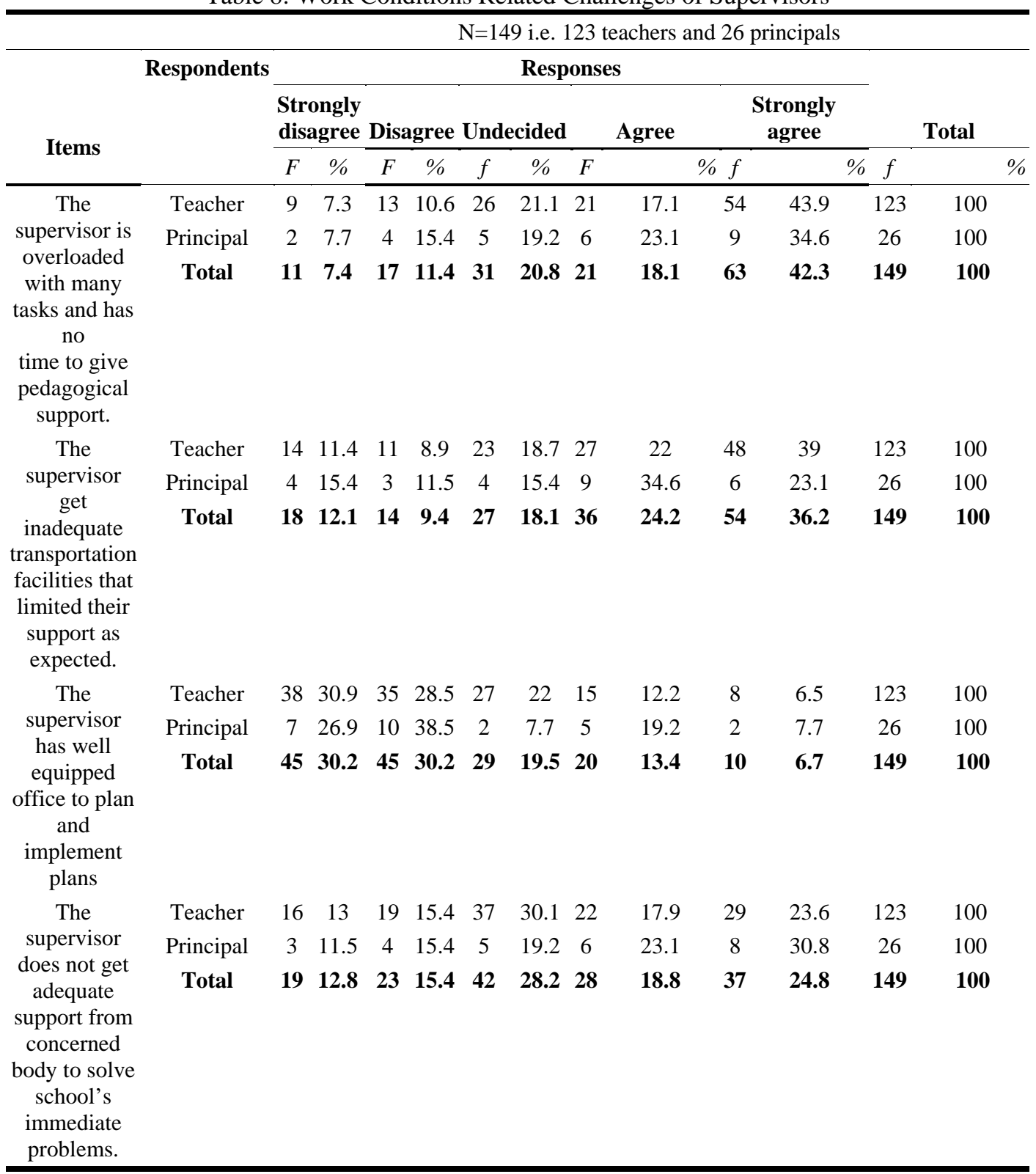

As depicted in table 8, the majority of both teachers (43.9\%) and principals (34.6\%) totally (42.3\%) respondents indicated that supervisors are overloaded with many tasks and have no time to give pedagogical support. The result of the Mann Whitney U Test for this item showed that there was no statistically significance difference at $\alpha=.05$ between the teachers and principals respondents opinions in which $(\mathrm{U}=1461.0, \mathrm{P}=.469)$.

Commenting on this, one of the supervisors put the condition as; 
I and other CRC supervisors are overburdened with many tasks in addition to being responsible for many schools. We take part in many activities in the education office, which are not directly related to our core activity.

Another supervisor put it with numerical evidences;

Here in Jimma town, I have to supervise and support 18 primary schools in which 3 are governmental and 15 are private schools. Look how difficult it is to visit all these schools and the teachers. It is painful, when we go to all these schools without transportation facility by paying out of our pockets. We are performing everything only with our commitments.

The education office supervision coordinator also confirmed the above claims by reporting;

Cluster supervisors are expected to visit schools as frequent as possible, but they could not always do this since they have many private and government schools to visit and support besides the various tasks they have to perform.

Teachers also indicated that supervisors come to school and take data, and always meet only the school principal. This shows that the practice of CRC supervisors is hampered with extra activities that limited provision of professional support to teachers.

In Table 8 the third item, respondents were asked about the availability of office adequately equipped with tables, chairs, cabinet etc. for CRC supervisors. Consequently, 73(59.3\%) teachers and 17(65.3\%) principals disagreed that there are such materials and facilities to the supervisors'. In the observation, it was identified that many supervisors lack such facility. Sometimes they share with principals.

According to the interview conducted with CRC supervisors and Jimma town Education Office Supervision Coordinator, lack of resources emerged as major challenge. In the interview, all respondents highlighted the problem of adequately equipped office. One CRC supervisor from Jiren said "Look at my office, no filling cabinet, every documents were put on desks, no computer, telephone, etc. to carry out my work..." while the other supervisor from Jimma CRC says "my office is very small, and as you see we cannot add any other third person, and it is difficult to have a meeting more than two or three people...”. Look how it is difficult to give professional support where supervisors begging resources from schools. The observation conducted by the researcher also confirmed that supervisors are working in an environment which is not conducive. From the quantitative data, the test result and the interview, it is possible to say that the working 
condition in terms of office and necessary equipment is in a poor condition for supervisors.

As shown in table 8 above, CRC supervisors were getting support from district office to solve school's immediate problems as shown by the majority (30.8\%) of the principal although $(30.1 \%)$ of the teachers were not able to decide on the issue. When the Mann Whitney $U$ Test has been utilized, there is no statistically significance difference at significance level of $\alpha=.05$ between the teachers and principals respondents $(\mathrm{U}=1435.0, \mathrm{P}=$ $.410)$ since $\mathrm{p}>0.05$.

\section{Discussion}

Cluster resource centers appear in many education systems as a device for increasing teachers' access to training and improve their capabilities to offer quality education in schools (Robinson, 2006, p. 4). Cluster resource center supervisors in Ethiopia are expected to encourage and provide training opportunities appropriate and adequate to enhance professional competence of teachers and also support in the delivery of the induction program for newly deployed teachers in schools (MoE, 2009b).

In this regard, the professional support given in the study area was found to be inconsistent and unsatisfactory. Moreover, the supervisors' involvement in the provision of induction training to new teachers to familiarize them with the environment and help them improve their instructional practices by demonstrating and modeling teaching techniques and methods was not to the expected level. The cluster supervisors hardly arranged workshops and seminars, and providing objective feedback for teachers on classroom observation. This finding is in agreement with Paulos (2001) who pointed out that many teachers complain that conferences and workshops at grassroots level are nonexistent.

According to Mbabo (2009), to ensure learning in all disciplines CRCs need to provide individual teacher and school with opportunities for continuous inquiries, training, meetings and workshops. On top of this, empirical studies in the US and Africa revealed that providing objective feedbacks on lessons positively affects teachers' reflective behavior and encourage try out of a variety of strategies to improve instruction (Blasé \& Blasé, 1999; Pansiri, 2008; Rous, 2004) cited in Baffour-Awuah (2011). Luel (2009) indicated that the performance of CRC supervisors is low in giving constructive feedback. Similarly, the findings of this study revealed that the supervisors were not able to give timely and constrictive feedbacks to help teachers improve their instruction.

It is generally believed that CRC supervisors play significant role in enhancing the professional competence of teachers. However, due to various reasons, these supervisors were found to be ineffective. Rous (2004) in this 
study of public primary schools did reveal that teachers benefit little from the supervisory service. In line with this, the results of the study agree with Rous (2004) that most teachers believe that they are not benefited from the support by CRC supervisors. As the finding of the study showed, CRC supervisors' classroom visit and comments did not successful in improving teachers' presentation, lesson planning and classroom management practices.

Teachers and principals benefit a lot by sharing experiences of colleagues working in the different schools. Dittmar, et.al (2002) states that when teachers get together to discuss and interpret syllabuses, and draw common schemes of work, they benefit a lot. Given the views expressed by the above scholars, the findings of the current study conclude that the CRC supervisors' support is far from the classroom practices and less successful in benefiting teachers in terms of promoting teachers' professional development at least in the major areas like lesson presentation, selection and use of instructional materials and teaching methods to improve the classroom practices and the quality of education.

School supervision is also expected to support school principals or leaders to improve their management practices. Giordano (2008) pointed out that facilitating and assisting local planning in more logical scale is among the objectives of school clustering. Evidence based decisions change schools (Bray, 1987). In line with these findings, this study showed that CRC supervisors are not providing need based training to improve planning skills of school management. They also failed to provide evidences to strengthen school decision making. The CRC supervisors were not sufficiently consulting the school management on how to use resources efficiently.

Concerning collaboration among teachers, principals and the community, findings of this study are in line with (Gashaw, 2008) that cluster supervisors had more contact with school principals. However, the collaboration among member schools, principals, and teachers regarding pedagogic issues was not to the expected level, and findings revealed that CRC supervisors fail to work as a linking agent between the school and the district office to enhance their relationship except creating contact with principals.

Promoting community school collaboration is important to eat the fruits of education quality. Giordano (2008:29); states that encouraging community school cooperation and community participation in education through school clustering is very important. Promoting collaboration among teachers is an important way to help schools change for the better (Sergiovanni \& Starratt, 1993). However, the study findings revealed that the CRC supervisors hardly work on advantages of collaboration for school effectiveness. They didn't sufficiently promote community school cooperation. 
Discharging supervisory roles and responsibilities effectively is not without challenges. In line with this, Holland's (2004) states that supervisors must offer evidence that they have the necessary knowledge and skills to make important decisions about instruction, and credentials in the form of degrees and diplomas are a form of evidence, however, credentials alone do not inspire trust. The findings of this study also revealed that CRC supervisors lack adequate qualification and competence to provide the supervisory service although they have diploma or degree. Lack of practical skills for good performance in providing supervisory support is the main challenge. CRC supervisors have long year work experience, but lack commitment and current professional competence. In line with this, Certo (2006) indicated that, neither promotion through experience nor hiring a qualified supervisor is a guarantee to know how to supervise.

The finding of the study also revealed that CRC supervisors accept responsibility for their decisions as a professional. Evidences from the interview result also showed similar idea. This shows that supervisors are confident to take professional responsibility for their decision. However, it was identified that lack of efficiency to apply the knowledge CRC supervisors get from workshops and seminars in providing advice and support as a challenge. With this regard Blasé and Blasé (1999) found that supervisors in public primary schools in the US provided their teachers with information about innovative seminars and workshops. Concerning availability important guidelines, the findings of this study revealed that CRC supervisors lack enough instruments such as manuals and guidelines. In line with this De Grauwe (2001) indicated that manuals and guidelines are inadequate for supervisors.

Of the challenges related to working conditions to supervisors is being overloaded with many tasks and number of schools to visit little time to give pedagogical support. Supervisors are very much occupied with many administrative tasks and duty of visiting many private and government schools. The study argues that 'supervisory staff has too many schools and teachers to cover to be able to visit them all regularly' (De Grauwe 2001:243). It is also indicated that 'assigning administrative and pedagogical tasks for a single person in a cluster can adversely affect the goal of improving education quality (Giordano, 2008:137) that the working conditions were not favorable for cluster supervisors to carry out frequent school visits as expected, and hindered with many obstacles. In line with the above finding, De Grauwe (2001) in his study of supervision in four African countries identified that in the offices of many supervisors relatively cheap items as filling cabinets are not found. In the same vein, UESCO (2007) also pointed out that the materials (office, equipment, etc) and human support 
service at the disposal of supervisors are the main obstacles to the efficient implementation of supervisory work in developing countries.

With regard to support from district education office, the finding of the study shows that there is encouraging practice. In relation to this, Giordano (2008) indicated that support from cluster coordinators support from the district level helps a lot. CRC supervisors' lack of adequate training, motivation and interest from the side of supervisors were identified as additional challenges in cluster supervision. In a study by De Grauwe (2001a) supervisors are frustrated for they lack authority to take actions. The need for motivation through improving working conditions, career development, and the like are recommened by De Grauwe (2001). On top of this, Ebmeier (2003) indicated that the supervisors' interest and commitment has an effect on teaching.

\section{Conclusion}

The study aimed to investigate the practice of primary School Cluster Supervision in Jimma town. From the results of the study is possible to conclude that teachers are not professionally benefited from the current supervisory practices of the CRC supervisors in the way that they could help them improve the quality of the teaching and learning and the education in general. The CRC supervisors are not promoting staff development to the expected level. The actual performance of the CRC supervisors did not meet the needs of teachers and the goals of bringing the supervision service closer to the schools. CRC supervisors are playing a positive role in ensuring good governance however they were not able to significantly improve school principals' management practices in terms of planning, decision making and internal management to advance the administrative service with the main focus to support the pedagogical aspects. The CRCs were supposed to create strong collaboration among stakeholders. Yet, the collaboration is less successful and restricted between the CRC supervisors and schools alone. In sum, the work of CRC supervisors is challenged with lack of practical competence and preparation of cluster supervisors on one hand and the poor working conditions of supervisors on the other hand.

\section{Recommendations}

Based on the above discussion and conclusions, it was recommended the CRC supervisors to focus on issues that will bring about school improvement in general and student performance in particular. This issues my included enhancing teachers competence and professional development strategies. Moreover, the CRC supervisors need to work with the concerned bodies at various levels of education management to create conductive working conditions. Regional Education Bureau and Jimma Town 
Education Office experts in collaboration with Education Colleges and Jimma University who have better expertise in the area of supervision need to provide adequate training for cluster supervisors to enhance their skills. Jimma town supervision coordinator should provide continuous orientation for supervisors to focus on improving teaching. In order to advance and fully contribute to the improvement of the school management practices, CRC supervisors are recommended to reconsider the way they provide support to the school principals in terms of planning, decision making and internal management with the main goal of improving teaching learning. Regional Education Bureau and Jimma Town Education office were also recommended to allocate budget for the CRC supervisor's work. The school community and local NGOs were also advised to improve the working conditions on this level by contributing important resources for the supervision and support service at the CRC level. Attention should be given by Educational Administrators to motivate and increase the CRC supervisors' interest through improving their working conditions and commitment.

\section{References:}

1. Al-Hammad, I. (2000). The obstacles of instructional supervision in Riyadh schools.Unpublished Master thesis. King Saud University: Riyadh.

2. Baffour-Awuah, P. (2011). Supervision of instruction in public primary schools in Ghana: teachers' and head teachers' perspectives. Murdoch University: Doctoral dissertation.

3. Bays, D. A. (2001). Supervision of special education instruction in rural public school districts: A grounded theory. Doctoral Dissertation.Faculty of the Virginia PolytechnicInstitute and State University.

4. Bethlehem, J. (2009) Applied Survey Methods: A statistical perspectives. USA:John Wiley \& Sons, Inc.

5. Biiroo Barnoota Oromiyaa (2000). Adeemsa hojii kenna deggarsa ogummaa fi hordoffii barnootaa. B.B.O.(OREB).

6. Blumberg, A. (1980). Supervisors and Teachers: A private cold war. Berkeley: McCutchan Publishing Corporation.

7. Chanyalew Woldegebriel (2005). The Practice and Problems of Instructional Supervision inSecondary Schools of Hadya Zone. AAU (Unpublished MA Thesis)

8. Cochran, W,G. (1977). Sampling Techniques ( $3^{\text {rd }}$ ed.). New York: Jhon Wiley and Sons.

9. De Grauwe, A. (2001a). School Supervision in four African countries: Challenges and reforms. Vol. I. Paris: IIEP/UNESCO. 
10. . (2001b). School supervision in four African countries: National Diagnosis. Vol. II. Paris: UNESCO/International Institute for Educational Planning.

11. Getachew, G. (2001). School Based Instructional Supervision In Selected Secondary Schools Of Addis Ababa. Unpublished Thesis: Addis Ababa University.

12. Giordano, E.A. (2008). School clusters and teacher resource center. Paris: IIEP/UNESCO.

13. Gashaw Debassu.(2008). Supervisory Practices of Cluster Primary School Supervisors in Promoting Teachers Professional Competence in West Gojjam Administrative Zone, Unpublished Master's Thesis, Addis Ababa University.

14. Glickman, C.D., Gordon, S.P., \& Ross-Gordon, J.M. (2005). The Basic Guide to Supervision and Instructional Leadership. Needham Heights, MA: Allyn\& Bacon.

15. Govinda, R.; Tapan S. (1999). Quality education through school based supervision and support: The case of GSS primary schools in Bangladesh. Paris: UNESCO/International Institute for Educational Planning.

16. Hoy, W. K. \& Forsyth, P. D. (1986). Effective supervision: Theory into practice. New York: Random House.

17. IIEP/UNESCO (2007). Reforming school supervision for quality improvement: Roles and functions of supervisors.(Module 2). Paris: UNESCO.

18. IIEP/UNESCO (2007). Reforming school supervision for quality improvement: Reinforcing school-site supervision (Module 6). Paris: UNESCO.

19. Lockheed, A. M. \&Verspoor, M. E. (1991).Improving primary education in developing countries.Washington DC: World Bank, Oxford University Press.

20. Kamindo, C. M. (2008) Instructional supervision in an era of change: policy and practice in primary education in Kenya, Durham theses, Durham University. Available at Durham E-Theses Online: http://etheses.dur.ac.uk/2195/

21. Knamiller, G. (1999). The effectiveness of the teacher resource center strategy [Electronic version]. Educational research paper NO.34.London: DFID.

22. Mbamba, M.S. (2009). The Role of Teachers' Resource Centres from the Perspective of School Managers and Teachers; Rhodes University: unpublished.

23. Million Morki.(2010). An assessment of the status of school based instructional supervision in secondary schools of west Arisi zone of 
Oromia region. Unpublished Master's Thesis, Addis Ababa University.

24. MoE (2001); Ethiopian supervision manual. Addis Ababa. Minster of Education.

25. (2006). Decentralized Management of Education: A Reference Manual, God Printing and Packing Program, Addis Ababa. (2008). General Education Quality Improvement Package. Addis Ababa. Minstery of Education.

26. _ (2010). Education Sector Development Program IV (ESDP IV): Program Action Plan, Federal Ministry of Education, Addis Ababa.

27. _ (2012). Ethiopian National Professional Standards Framework for School Supervisors. Addis Ababa: Ministry of Education.

28. Oliva, P. F. \& Pawlas, (1997). Supervision for today's schools.(5th ed.). New York: Longman.

29. Pomuti, H. N. (2008). An analysis of the relationship between cluster-based school management and improving teaching in Namibian schools (Doctoral dissertation, University of Pretoria).

30. Singh, W.K. (2006). Fundamentals of research methodology and statistics; New Delhi: New age international publishers.

31. Sullivan, S. \& Glanz, J. (2000). Supervision that improves teaching: Strategies and techniques.Thousand Oaks, CA: Corwin Press Inc.

32. Tashakkori, A., \& Teddlie, C. (2003a). Issues and Dilemmas in Teaching Research Methods Courses in Social and Behavioural Sciences: US perspectives. International Journal of Social Research Methodology, 6 (l), 61 - 77.

33. Tesfaw T.A.; Hofman R.H. (2012). Instructional Supervision and Its Relationship with Professional Development: Perception of private and government secondary school teachers in Addis Ababa.

34. TGE (1994).Education and Training Policy. Addis Ababa: St. George Printing Press.

35. Wiles, J. \& Bondi, J. (1996). Supervision: A guide to practice (4th ed.). Englewood Cliffs, N.J.: Merrill. 